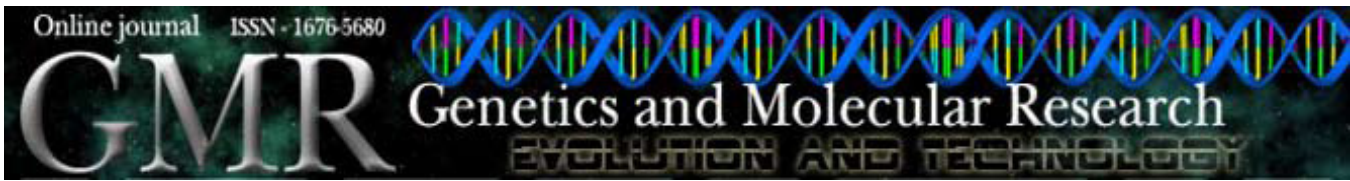

\title{
Mutagenic potential and modulatory effects of the medicinal plant Luehea divaricata (Malvaceae) in somatic cells of Drosophila melanogaster: SMART/wing
}

\author{
L.P. Felício ${ }^{1}$, E.M. Silva ${ }^{1}$, V. Ribeiro ${ }^{1}$, C.T. Miranda ${ }^{3}$, I.L.B.F. Vieira ${ }^{4}$, \\ D.C.S. Passos ${ }^{4}$, A.K.S. Ferreira ${ }^{1}$, C.R. Vale ${ }^{1}$, D.C.S. Lima ${ }^{1}$, S. Carvalho ${ }^{1}$ \\ and W.B. Nunes ${ }^{2}$ \\ 'Departamento de Biologia Geral, Instituto de Ciências Biológicas, \\ Universidade Federal de Goiás, Goiânia, GO, Brasil \\ ${ }^{2}$ Departamento de Morfologia, Instituto de Ciências Biológicas, \\ Universidade Federal de Goiás, Goiânia, GO, Brasil \\ ${ }^{3}$ Faculdade de Tecnologia, Universidade de Brasília, Brasília, DF, Brasil \\ ${ }^{4}$ Departamento de Bioquímica e Biologia Molecular, \\ Instituto de Ciências Biológicas, Universidade Federal de Goiás, \\ Goiânia, GO, Brasil
}

Corresponding author: L.P. Felício

E-mail: lpfelicio@hotmail.com

Genet. Mol. Res. 10 (1): 16-24 (2011)

Received November 23, 2010

Accepted December 20, 2010

Published January 4, 2011

DOI $10.4238 /$ vol10-1gmr982

ABSTRACT. Luehea divaricata is a native plant of the Brazilian Cerrado, known as "açoita-cavalo". It is used as a popular herbal medicine in the treatment of dysentery, bleeding, arthritis, tumors, ulcers, and gangrenous wounds. Considering that herbal medicines sometimes provoke tumors and/or may prevent mutational events, it is important to study the action of these natural drugs on DNA. Aqueous extract of the bark of $L$. divaricata was evaluated at three different concentrations $(0.10,0.30,0.50 \mathrm{mg} / \mathrm{mL})$, individually and in combination with the neoplastic drug doxorubicin (DXR), by the somatic mutation and recombination test (SMART/wing) 
in Drosophila melanogaster. Distilled water was included as a negative control. The mutation frequency in the treatments with $L$. divaricata extract alone was not significantly higher than in the negative control for standard (ST) and high bioactivation (HB) crosses. When L. divaricata extract was combined with DXR, there was a significant reduction in the frequency of spots when compared to DXR alone, in both crosses. Further studies with other experimental models would be useful to confirm that $L$. divaricata extract is not harmful and that it could be used in the prevention of cancer.

Key words: Luehea divaricata; Drosophila melanogaster; SMART/wing; Genotoxicity; Anti-genotoxicity

\section{INTRODUCTION}

Medicinal plants have been widely used by urban and rural populations in treating various diseases, constituting an effective and less expensive therapy (Ioris, 1999).

Phytotherapy is based on old traditions, widely disseminated through salespeople, healers, faith healers, part of the culture of indigenous people, and rural areas. Of all the 365,000 species of flowering plants, it is estimated that only $8 \%$ of them have been systematically studied in terms of constituents. Nevertheless, approximately 7000 substances of pharmaceutical importance have been isolated from plants known for their medicinal properties, and several constituents have been processed into pharmaceuticals (Campelo, 2006).

Brazil has $19 \%$ of all species of these already described plants (Giulietti et al., 2005), and most of these are in the Cerrado. Some studies suggest that the analysis of the bioactivity of medicinal plants from the Cerrado could provide the basis for the production of new drugs (Silva et al., 2003).

Luehea divaricata Mart. et Zucc. (Malvaceae), popularly known in Brazil as "açoita-cavalo", "açoita-cavalo miúdo", "ibatingui", "ivatingui", "pau-de-canga", and "caiboti", is a large tree (15$25 \mathrm{~m}$ ) found in the Brazilian States of Bahia and Rio Grande do Sul (Lorenzi, 1998). Its wood has great flexibility and is used by farmers in the manufacture of whips.

In phytotherapeutic treatment, it is indicated for baths and enemas and for cases of dysentery and bleeding; a decoction of the bark is used to treat arthritis, rheumatism and leukorrhea. The decoction of bark is excellent for treating cases of tumors and gangrenous wounds (Balbach, 1993). Carvalho (2006) has shown its efficacy in the treatment of gastric ulcers and to help in wound healing in rats by the use of a hydroalcoholic extract of its bark. Müller et al. (2006) proved the effectiveness of the methanol extract and liquid fractions of the leaves against bacteria.

The bark extract contains as main components flavonoids, tannins, anthocyanins, and triterpenes (Siqueira, 2006), and epicatechin is included among the active ingredients of the extract (Tanaka et al., 2005).

Since the use of plants whose toxicological characteristics are unknown can lead to the occurrence of somatic mutational events in humans, many tests have been developed to evaluate genotoxicity and antigenotoxicity.

The somatic mutation and recombination test (SMART)/wing test, developed by Graf et al. (1984), is considered to be quick and inexpensive and gives reliable results, which are unambiguous and highly reproducible. The test is useful to detect genetic changes that occur in the wing's imaginal 
disc. It is based on the fact that during the early development of Drosophila melanogaster, groups of cells of imaginal discs separate and proliferate during larval growth to differentiate during metamorphosis into structures of the adult body (eyes, wings, etc.) (Graf et al., 1984).

In the SMART/wing test two markers are used, with well-defined expressions. The marker multiple wing hairs $(m w h)$, in the homozygous condition, results in multiple trichomes per cell, instead of the usual single trichome. The marker flare $3\left(f r r^{3}\right)$ is a recessive mutation that affects the shape of the trichome. It produces the malformed trichome that is shaped like a flame. The mutant allele $f r^{3}$ is lethal in the homozygous recessive zygotes (zygotes homozygous for the allele $\mathrm{fr}^{3}$ are not able to develop into adult flies). In contrast, homozygous cells of the imaginal disc are viable and lead to the formation of mutant cells in the wings. Due to the lethality in the zygote, the allele $f r^{3}$ is kept in line stock with the presence of a "balancer chromosome" with multiple chromosomal inversions, TM3 (Gusmán-Rincón and Graf, 1995).

\section{MATERIAL AND METHODS}

\section{Plant material}

The bark and inner bark powder of $L$. divaricata was obtained at a specialty market, Santa Fé - Manipulation pharmacy, Goiânia, GO. The aqueous extract of $L$. divaricata (AELd) was prepared at the time of treatment, using distilled water.

The extract was used to produce a survival curve using concentrations of $0.10,0.20$, $0.30,0.40$, and $0.50 \mathrm{mg} / \mathrm{mL}$. Three of these doses $(0.10,0.30$ and 0.50$)$ were chosen for the mutagenesis and antimutagenesis experiments.

\section{Doxorubicin}

Doxorubicin (DXR, Doxolen lyophilized, Eurofarma Laboratórios Ltda., São Paulo, Brazil, CAS No. 23214-92-8), dissolved in distilled water in the dark at a concentration of $0.125 \mathrm{mg} / \mathrm{mL}$, was used as the positive control and distilled water as the negative control.

\section{Survival curve}

To determine the cytotoxic potential of AELd, five different concentrations were prepared in duplicate $(0.10,0.20,0.30,0.40$, and $0.50 \mathrm{mg} / \mathrm{mL})$ by dissolving the powder in distilled water at the time of treating D. melanogaster third-stage larvae. We used exactly 100 larvae/concentration and the emerging adults were recorded. The results were compared to the negative control.

\section{Somatic mutation and recombination test}

\section{Drosophila strains and crosses}

Three strains of $D$. melanogaster were used: 1) multiple wing hairs: $y ; m w h j$ ( $m w h$, 3-0.3); 2) flare-3 (flr3, 3-38.8) (flr3/In(3LR)TM3, ri pp sep I(3)89Aa bx34e and Bd'); 3) ORR/ ORR; frr3/In(3LR)TM3, ri pp sep I(3)89Aa bx34e and $B d^{\$}$. To produce the standard (ST) cross, 
stocks of flare-3 werw virgin females were crossed with stocks of $m w h$ males (Graf et al., 1989). The high bioactivation (HB) cross, which has high levels of cytochrome P450, was obtained by crossing ORR; flare-3 werw virgin females with $m w h$ males (Graf and van Schaik, 1992).

Both crosses produced experimental larval progeny that consisted of marker-heterozygous $(\mathrm{MH})$ flies $(m w h+/+$ flare-3) with phenotypically wild-type wings and balancer-heterozygous (BH) flies ( $m w h+/+$ TM3 Bds) with phenotypically serrate wings (Saner et al., 1996).

\section{Larval feeding}

Eggs from the ST and HB crosses were collected over an 8-h period and maintained in culture bottles containing a solid agar base (3\%, w/v) covered with a layer of live baker's yeast (Saccharomyces cerevisiae) supplemented with sucrose. For the treatments, 72-h-old larvae were removed from the culture bottles and washed in tap water with the help of a fine mesh stainless steel strainer.

The larvae from both crosses were transferred to glass tubes containing $0.9 \mathrm{~g}$ synthetic medium (form 4-24, Carolina Biological Supply Co., Burlington, USA) dissolved in $3.0 \mathrm{~mL}$ of a solution containing AELd with or without DXR at $0.125 \mathrm{mg} / \mathrm{mL}$, which is a concentration known to be genotoxic to $D$. melanogaster somatic cells. The results obtained for the mutagenesis assay were compared to that of the negative control, and those for the antimutagenesis assay (AELd + DXR) were compared to that of the positive control $(0.125 \mathrm{mg} / \mathrm{mL} \mathrm{DXR})$. Since some of the compounds are photosensitive, all the tubes were wrapped in aluminum foil. The larvae were fed on the medium until their larval life was complete ( 2 days). The experiments were performed at $25^{\circ} \mathrm{C}$ and relative humidity of $60 \%$.

\section{Analysis of adult flies}

After hatching, individual adult flies were collected and stored in $70 \%$ ethanol. The wings of MH flies were removed, mounted in Faure's solution, and examined for spots using a compound microscope at $400 \mathrm{X}$ magnification. During the analysis, the positions of the spots were recorded according to wing sections (Graf et al., 1984). Single spots resulted from point mutations, chromosome aberrations, or recombination events, while twin spots (flare and $m w h$ ) were produced by mitotic recombination between the proximal marker flare and the centromere of chromosome 3 .

\section{Statistical analysis}

The $\chi^{2}$ test was used to evaluate the mutagenic potential (Frei and Wügler, 1988). The study presents a comparison of the number of different classes of spots found between the treatments and their negative control. For the antimutagenic analysis, the frequencies of each type of spot for each treatment group were compared pairwise (DXR vs AELd + DXR in each class analyzed), using the nonparametric Mann-Whitney U-test and Wilcoxon rank sum tests (Frei and Würgler, 1995).

\section{RESULTS}

For analysis of AELd cytotoxic potential 5 doses were chosen $(0.10,0.20,0.30,0.40,0.50 \mathrm{mg} /$ $\mathrm{mL}$ ), with two replicates per dose and a median between the number of survivors. The results of the 
survival curve are shown in Figure 1. An analysis of the data shows that the AELd does not have any cytotoxic effect on the descendants of both crosses, ST and HB, when compared to the negative control.

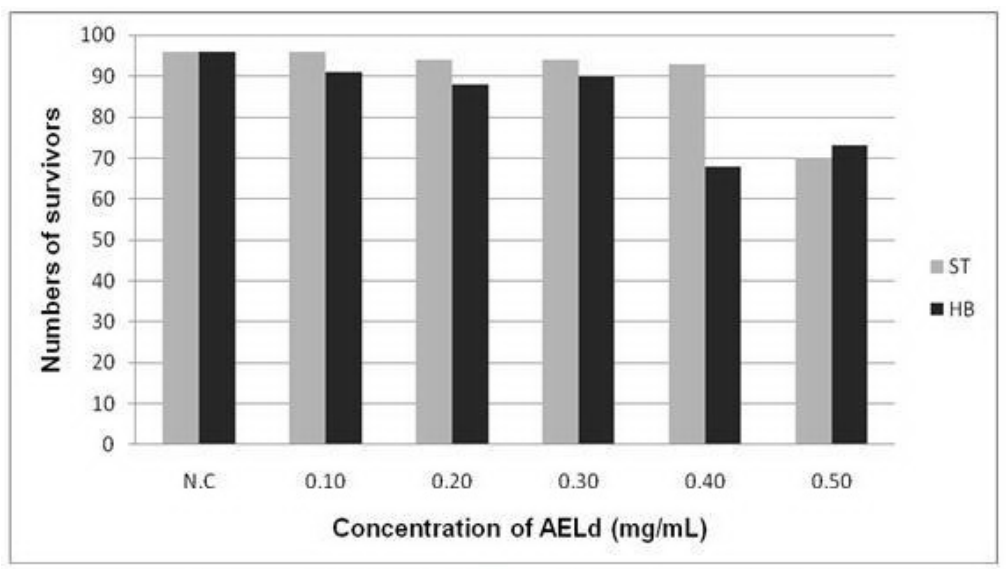

Figure 1. Survival curves of descendants of Drosophila melanogaster from standard (ST) and high bioactivation (HB) crosses fed different concentrations $(0.10,0.20,0.30,0.40$, and $0.50 \mathrm{mg} / \mathrm{mL})$ of aqueous extract of Luehea divaricata (AELd). $\mathrm{NC}=$ negative control.

To determine the possible genotoxic and/or antigenotoxic effect, 1280 wings were analyzed from emerging adults of three independent experiments, including the negative control (sterile distilled water) and positive control (DXR $-0.125 \mathrm{mg} / \mathrm{mL}$ ) and 3 different concentrations $(0.10,0.30,0.50 \mathrm{mg} / \mathrm{mL})$ of AELd alone and in combination with DXR $(0.125 \mathrm{mg} /$ $\mathrm{mL}$ ). Larvae of the ST and HB crosses were treated simultaneously, in order to standardize the environmental conditions of the experiments. The results of mutagenesis, obtained in the analysis of the MH (trans-heterozygous) descendants of ST and HB crosses, treated with different concentrations of AELd, are presented in Table 1.

Table 1. Frequency of mutant spots observed in marker-heterozygous trans-heterozygous descendants of Drosophila melanogaster from standard (ST) and high bioactivation (HB) crosses treated with three different concentrations $(0.10,0.30$ and $0.50 \mathrm{mg} / \mathrm{mL})$ of aqueous extract of Luehea divaricata (AELd).

\begin{tabular}{|c|c|c|c|c|c|c|c|c|c|}
\hline \multirow{2}{*}{$\begin{array}{l}\text { Concentrations } \\
(\mathrm{mg} / \mathrm{mL})\end{array}$} & \multirow{2}{*}{$\begin{array}{c}\text { No. of } \\
\text { individuals }(\mathrm{N})\end{array}$} & \multicolumn{7}{|c|}{ Frequency of mutant spots per individual (No. of spots) ${ }^{\mathrm{a}}$} & \\
\hline & & $\begin{array}{c}\text { SSS }(1-2 \text { cells })^{\mathrm{b}} \\
\mathrm{m}=2\end{array}$ & & $\begin{array}{c}\text { SBS }(>2 \text { cells })^{b} \\
m=5\end{array}$ & & $\begin{array}{l}\text { TWS } \\
\mathrm{m}=5\end{array}$ & & $\begin{array}{l}\text { TOS } \\
\mathrm{m}=2\end{array}$ & \\
\hline \multicolumn{10}{|l|}{$\overline{\mathrm{ST}}$} \\
\hline Negative control & 40 & $0.58(23)$ & & $0.18(7)$ & & $0.05(2)$ & & $0.80(32)$ & \\
\hline 0.10 & 40 & $0.23(9)$ & - & 0.03 (1) & - & $0.03(1)$ & $\mathrm{i}$ & $0.28(11)$ & - \\
\hline 0.30 & 40 & $0.28(11)$ & - & $0.08(3)$ & - & $0.03(1)$ & $\mathrm{i}$ & $0.38(15)$ & - \\
\hline 0.50 & 40 & 0.28 (11) & - & $0.05(2)$ & - & $0.05(2)$ & $\mathrm{i}$ & $0.38(15)$ & - \\
\hline DXR & 40 & $2.80(112)$ & + & $3.65(146)$ & + & $3.10(124)$ & + & $9.55(382)$ & + \\
\hline \multicolumn{10}{|l|}{ HB } \\
\hline Negative control & 40 & $1.15(46)$ & & $0.23(9)$ & & $0.03(1)$ & & $1.40(56)$ & \\
\hline 0.10 & 40 & $0.10(4)$ & - & $0.13(5)$ & - & $0.00(0)$ & $\mathrm{i}$ & $0.23(9)$ & - \\
\hline 0.30 & 40 & $0.23(9)$ & - & 0.03 (1) & - & $0.00(0)$ & $\mathrm{i}$ & $0.25(10)$ & - \\
\hline 0.50 & 40 & $0.13(5)$ & - & $0.05(2)$ & - & $0.03(1)$ & $\mathrm{i}$ & $0.20(8)$ & - \\
\hline DXR & 40 & $3.40(136)$ & + & $4.80(192)$ & + & $3.75(150)$ & + & $11.95(478)$ & + \\
\hline
\end{tabular}

a Statistical diagnosis according to Frei and Würgler (1988): +, positive; -, negative; i, inconclusive. $\alpha=\beta=0.05$. ${ }^{b}$ Including rare single spot $\mathrm{flr}^{3} . \mathrm{m}=$ multiplication factor; SSS = simple small spots; SBS = simple big spots; TWS $=$ twin spots; TOS $=$ total spots. 
The data, when compared to the negative control, did not reveal a statistically significant $(\alpha=0.05)$ difference in the total number of spots, small single spots and large single spots in both ST and HB crosses. Concerning the number of twin spots, the results were inconclusive, suggesting that it is necessary to increase the sample to determine whether or not there is any statistical significance of data compared to the negative control. The results indicate that AELd did not show any direct genotoxic effect, based on the analysis of ST crosses, or indirect genotoxic effect, according to HB crosses, on the somatic cells of D. melanogaster.

Table 2 presents the data on the antigenotoxic effect of co-treatment with different concentrations of AELd and DXR $(0.125 \mathrm{mg} / \mathrm{mL})$, obtained by the analysis of MH descendants from ST and HB crosses. The data show statistically significant reductions $(\alpha=0.05)$ in both crosses, ST and HB, and in the frequencies of small single spots, large simple spots, twin spots, and total spots when compared to the positive control.

\begin{tabular}{|c|c|c|c|c|c|c|c|c|c|}
\hline \multirow{2}{*}{$\begin{array}{l}\text { Concentrations } \\
(\mathrm{mg} / \mathrm{mL})\end{array}$} & \multirow{2}{*}{$\begin{array}{c}\text { No. of } \\
\text { individuals }\end{array}$} & \multicolumn{8}{|c|}{ Frequency of mutant spots per individual (No. of spots) ${ }^{a}$} \\
\hline & & $\begin{array}{c}\text { SSS }(1-2 \text { cells })^{b} \\
m=2\end{array}$ & & $\begin{array}{c}\text { SBS }(>2 \text { cells })^{b} \\
\mathrm{~m}=5\end{array}$ & & $\begin{array}{l}\text { TWS } \\
\mathrm{m}=5\end{array}$ & & $\begin{array}{c}\text { TOS } \\
\mathrm{m}=2\end{array}$ & \\
\hline \multicolumn{10}{|l|}{ ST } \\
\hline DXR & 40 & $2.80(112)$ & & $3.65(146)$ & & 3.10 (124) & & $9.55(382)$ & \\
\hline $0.10+\mathrm{DXR}$ & 40 & $1.10(44)$ & $\downarrow$ & $0.35(14)$ & $\downarrow$ & $0.25(10)$ & $\downarrow$ & $1.70(68)$ & $\downarrow$ \\
\hline $0.30+\mathrm{DXR}$ & 40 & $0.38(15)$ & $\downarrow$ & $0.35(14)$ & $\downarrow$ & $0.23(9)$ & $\downarrow$ & $0.95(38)$ & $\downarrow$ \\
\hline $0.50+$ DXR & 40 & $0.30(12)$ & $\downarrow$ & $0.45(16)$ & $\downarrow$ & $0.40(16)$ & $\downarrow$ & $1.15(46)$ & $\downarrow$ \\
\hline \multicolumn{10}{|l|}{ HB } \\
\hline DXR & 40 & 3.40 (136) & & $4.80(192)$ & & $3.75(150)$ & & 11.95 (478) & \\
\hline $0.10+\mathrm{DXR}$ & 40 & $1.10(44)$ & $\downarrow$ & $1.40(56)$ & $\downarrow$ & $0.53(21)$ & $\downarrow$ & $3.03(121)$ & $\downarrow$ \\
\hline $0.30+\mathrm{DXR}$ & 40 & $0.55(22)$ & $\downarrow$ & $0.55(22)$ & $\downarrow$ & $0.20(8)$ & $\downarrow$ & $1.30(52)$ & $\downarrow$ \\
\hline $0.50+\mathrm{DXR}$ & 40 & $0.90(36)$ & & $0.20(8)$ & & $0.28(11)$ & & $0.20(55)$ & \\
\hline
\end{tabular}

a Statistical diagnosis according to Frei and Würgler (1995): $\downarrow$ reduction in frequency of mutant spots. $\chi^{2}$ test, two-tailed, to compare proportions. ${ }^{b}$ Including rare single spot $\mathrm{flr}^{3}$. Significance level: $\alpha=\beta=0.05 . \mathrm{m}=$ multiplication factor; SSS $=$ simple small spots; $\mathrm{SBS}=$ simple big spots; $\mathrm{TWS}=$ twin spots; $\mathrm{TOS}=$ total spots.

Differences in the frequencies of all categories of spots observed in the mutant transheterozygous individuals scored $(\mathrm{MH})$ treated with DXR alone and DXR combined with the different concentrations of AELd were statistically significant $(\mathrm{P}<0.05)$, when compared to the negative control in both crosses.

AELd showed a reduction in the number of mutant spots for all classes, suggesting a modulating effect on the DNA damage caused by doxorubicin in somatic cells of the imaginal discs of D. melanogaster. The frequency of positive control spots showed a statistically significant increase in all categories when compared to the negative control. These results confirm the validity of the test.

\section{DISCUSSION}

Most of the approximately 25,000 human genes (Nussbaum et al., 2008), compared to the 13,000 mapped to Drosophila, originated from duplications and elaborations of their counterparts in insects (Miklos and Rubin, 1996). Due to the extraordinary conservation of 
molecular and metabolic pathways between flies and humans and to a significant homology for various oncogenes and tumor suppressor genes also found between these organisms, the results of biological assays using Drosophila as a model organism show metabolism similar to that found in humans (Artavanis-Tsakonas et al., 1995).

The offspring in the ST and HB crosses show two distinct progeny, $\mathrm{MH}$ and $\mathrm{BH}$, phenotypically identified by the presence of flat and serrated wings, respectively. The analysis of the $\mathrm{MH}$ descendants allows the identification of possible effects of chromosomal aberrations, point mutations and mitotic recombinations, and the analysis of the $\mathrm{BH}$ reveals the occurrence of recombination events (Graf et al., 1984; Graf and van Schaik, 1992).

\section{Cytotoxicity}

The data presented in Figure 1 show that there were no statistically significant differences in the number of emerging adults between the control group and the AELd-treated groups at the concentrations tested. The dose with the highest fatality rate was $0.50 \mathrm{mg} / \mathrm{mL}$ for ST and $0.40 \mathrm{mg} / \mathrm{mL}$ to $\mathrm{HB}$; however, none of the concentrations tested caused less than $50 \%$ survival, suggesting no cytotoxic effect at the doses tested. Therefore, we can conclude that AELd, under these experimental conditions, is not cytotoxic to the somatic cells of D. melanogaster.

\section{Genotoxicity}

An analysis of Table 1 shows that there was no statistically significant increase in the number of mutations in all classes analyzed, except twin spots, when compared to negative control.

The negative control (distilled water) had a higher number of spontaneous mutations in HB compared to ST crosses, which is consistent with data from the literature (Nunes, 2004; Mendanha et al., 2010; Passos et al., 2010). For the positive control, there was a statistically significant increase in the number of mutations, compared to the negative control, which validates the use of the test, and demonstrates its good response to mutagenic agents, such as DXR (Graf et al., 1984; Franchi et al., 2008).

As observed by Passos et al. (2010) with the extract of Palicourea coriacea Cham, the number of mutations in the negative control was, for both crosses, higher than that at the doses tested. Thus, the data indicate a possible protective effect by AELd against spontaneous mutations.

Therefore, we conclude that, under these experimental conditions and concentrations tested, AELd does not have a direct mutagenic effect (analyzing the ST cross) or indirect mutagenic effect (analyzing the HB cross), proving that the enzyme system related to cellular detoxification through cytochrome P450 does not interfere with the genotoxicity effect of the extract in the somatic cells of D. melanogaster.

\section{Antigenotoxicity}

A statistically significant reduction in the number of mutations of all classes was found with the co-treatments (AELd + DXR), in contrast to the findings for the positive control (DXR $0.125 \mathrm{mg} / \mathrm{mL}$ ), as shown in Table 2 . 
As expected, the positive control (DXR) had higher rates of mutations in the offspring of the HB cross when compared to the ones from the ST cross (Graf and van Schaik, 1992). This fact can be explained by high activities of cytochrome P450 enzymes, which help metabolize the drug and its transformation into free radicals.

The decrease in the number of small spots in the ST cross proved to be dose-dependent. This fact could also be observed with respect to the frequency of large single spots in the HB cross.

Similar results were found in tests using other herbal medicines with active ingredients similar to those present in L. divaricata, such as in the analysis of aqueous extracts of Ginkgo biloba (Nunes, 2004), Byrsonima verbascifolia (Mendanha et al., 2010) and P. coriacea (Passos et al., 2010). All these experiments were conducted with the SMART/wing test.

As observed in Table 2, we can consider that AELd is a desmutagenic agent, whereas when combined with DXR, it acts as a scavenger of free radicals induced by DXR, and/or by blocking its interaction with DNA. AELd is rich in compounds such as tannins, flavonoids and triterpenes, which may be responsible for the modulating action on DXR-induced effects on DNA (Nunes, 2004; Mendanha et al., 2010).

According to Robert and Gianni (1993), the cytotoxic effect of DXR is due to its transformation into semiquinone free radicals, leading to cell death from DNA damage. Therefore, anticancer therapies are cytotoxic to cancer cells, but eventually also affect healthy cells.

The combined use of compounds with modulating action to lessen the genotoxic effects of anticancer treatments on healthy cells may prove to be an important factor in maintaining the health of patients, since it does not interfere with its effects on tumor cells (Takeuchi et al., 2007).

Therefore, the results demonstrate that the modulating action of AELd may serve as a basis for studies aimed at developing a new drug as a co-adjuvant in chemotherapy.

\section{CONCLUSION}

Based on the analysis of survival curve and the experimental conditions, we conclude that AELd is not cytotoxic and should not be considered a direct or indirect mutagen. Besides, AELd showed in both ST and HB crosses a modulating effect on the damage induced by DXR. Therefore, studies with other organisms are warranted to ensure that the use of the herbal Luehea divaricata does not present risks to human health, validating their evaluation in anticancer therapies.

\section{REFERENCES}

Artavanis-Tsakonas S, Matsuno K and Fortini ME (1995). Notch signaling. Science 268: 225-232.

Balbach A (1993). As Plantas Curam. Editora Missionária, Itaquaquecetuba.

Calixto JB (2000). Biopirataria - A Diversidade Biológica na Mira da Indústria Farmacêutica. Ciência Hoje, Rio de Janeiro. 36-43.

Campelo PMS (2006). Plantas Medicinais e Seus Extratos: A Necessidade de Estudos Continuados. Estud. Biol. $28: 62$.

Carvalho JE (2006). Atividade antiulcerogênica e anticâncer de produtos naturais e de síntese. Multiciência 7: 1-18.

Franchi LP, Guimarães NN, Lehmann M, Andrade HHR, et al. (2008). Ausência de efeito tóxicogênico de Morinda citrifolia (NONI) em células somática de Drosophila melanogaster. Rev. Eletrônica Farm. 5: 46-536.

Frei H and Würgler FE (1988). Statistical methods to decide whether mutagenicity test data from Drosophila assays indicate a positive, negative, or inconclusive result. Mutat. Res. 203: 297-308.

Frei H and Würgler FE (1995). Optimal experimental design and sample size for the statistical evaluation of data from somatic mutation and recombination tests (SMART) in Drosophila. Mutat. Res. 334: 247-258. 
Giulietti AM, Harley RM, Queiroz LP, Wanderley MG, et al. (2005). Biodiversidade e conservação das plantas no Brasil. Megadiversidade 1: 52-61. Avaliable at [http://www.agencia.cnptia.embrapa.br/recursos/BIOD_ConservacaoIDeWNPNpKEJw.pdf]. Accessed November 22, 2010.

Graf U and van Schaik N (1992). Improved high bioactivation cross for the wing somatic mutation and recombination test in Drosophila melanogaster. Mutat. Res. 271: 59-67.

Graf U, Wurgler FE, Katz AJ, Frei H, et al. (1984). Somatic mutation and recombination test in Drosophila melanogaster. Environ. Mutagen. 6: 153-188.

Graf U, Frei H, Kagi A, Katz AJ, et al. (1989). Thirty compounds tested in the Drosophila wing spot test. Mutat. Res. 222: 359-373.

Gusmán-Rincón J and Graf U (1995). Drosophila melanogaster Somatic Mutation and Recombination Test as a Biomonitor. In: Biomonitors and Biomarkers as Indicators of Environmental Change. Plenum Press, New York, 169-181.

Ioris EM (Org.) (1999). Plantas Medicinais do Cerrado: Perspectivas Comunitárias para a Saúde, o Meio Ambiente e o Desenvolvimento Sustentável. $1^{\circ}$ edição. Fundação Integrada Municipal de Ensino Superior, Mineiros.

Lorenzi H (1998). Árvores Brasileiras: Manual de Identificação e Cultivo de Plantas Arbóreas Nativas do Brasil. Plantarum, Nova Odessa.

Mendanha DM, Ferreira HD, Felicio LP, Silva EM, et al. (2010). Modulatory effect of Byrsonima verbascifolia (Malpighiaceae) against damage induced by doxorubicin in somatic cells of Drosophila melanogaster. Genet. Mol. Res. 9: 69-77.

Miklos GL and Rubin GM (1996). The role of the genome project in determining gene function: insights from model organisms. Cell 86: 521-529.

Müller JB, Ceron CS, Kuntz VT and Pozzatti P (2006). Avaliação da Suscetibilidade Antifúngica e Antibacteriana do Extrato Bruto e Frações das Folhas de Luehea divaricata Martius. Anais da 58ª Reunião Anual da SBPC, Florianópolis.

Nunes WB (2004). Efeito Modulador do Extrato Aquoso Padronizado de Ginkgo biloba (EGb 761) Contra Mutações e Recombinações Somáticas Induzidas pela Doxorrubicina em Células Somáticas de Drosophila melanogaster. Doctoral thesis, UFU, Uberlândia.

Nussbaum RL, McInnes RR and Willard HF (2008). Genética Médica. $7^{\mathrm{a}}$ edição. Elsevier, Rio de Janeiro.

Passos DC, Ferreira HD, Vieira IL, Nunes WB, et al. (2010). Modulatory effect of Palicourea coriacea (Rubiaceae) against damage induced by doxorubicin in somatic cells of Drosophila melanogaster. Genet. Mol. Res. 9: 1153-1162.

Robert J and Gianni L (1993). Pharmacokinetics and metabolism of anthracyclines. Cancer Surv. 17: 219-252.

Saner C, Weibel B, Wurgler FE and Sengstag C (1996). Metabolism of promutagens catalyzed by Drosophila melanogaster CYP6A2 enzyme in Saccharomyces cerevisiae. Environ. Mol. Mutagen. 27: 46-58.

Silva LD, Nascimento V, Santos SC, Morais JOR, et al. (2003). Análise morfométrica das células de cloro de Poecilia vivipara expostas a frações da folha e da casca do caule de Caryocar brasiliensis. Portal de Periódicos da UEM. Available at [http:// www.periodicos.uem.br/ojs/index.php/ActaSciBiolSci/article/viewFile/2107/1545]. Accessed November 22, 2010.

Siqueira MG (2006). Atividade Antiulcerogênica do Extrato Bruto Hidroalcoólico da Luehea divaricata Martus et Zuccarini. 100 f. Master's thesis, UNICAMP, Campinas.

Takeuchi PL, Antunes LM and Takahashi CS (2007). Evaluation of the clastogenicity and anticlastogenicity of vitamin B6 in human lymphocyte cultures. Toxicol. In Vitro 21: 665-670.

Tanaka JCA, Silva CC, Dias Filho BP and Nakamura CV (2005). Constituintes Químicos de Luehea divaricata Mart. (Tiliaceae). Quím. Nova 5: 834-837. 